\title{
IMPROVING THE STUDENTS' READING SKILL THROUGH CLOZE PROCEDURE TECHNIQUE
}

\author{
Hendra Eka Putra \\ Program studi Pendidikan Bahasa Inggris Sekolah Tinggi Agama Islam Negeri Batusangkar \\ Korespondensi: Jl. Simpang Bendang No. 2 Tigo Tumpuak Lima Kaum Batusangkar \\ e-mail: hendra_kadam@yahoo.com
}

\begin{abstract}
Lack of ability in comprehending English texts is students' big problem nowadays. They fail in comprehending or grasping information from reading materials. As a result, their motivation decreases which in turn can inbibit their reading comprehension. In reading comprehension class, those difficulties faced by the students may be caused by many factors such as, reading materials, teaching method, media used and so forth. Related to the problem, cloze procedure technique can be used as an alternative technique for teaching reading. And, under the teacher's supervision the students also can enrich their reading skill, even their English vocabulary through this technique.
\end{abstract}

Kata kunci: reading, reading skill, cloze procedure, technique

\section{INTRODUCTION}

$\mathrm{M}$

any teachers complain that most of language learners face difficulties in comprehending reading materials. They fail in comprehending or grasping information from reading materials, and cannot interact with the text. Consequently, they lose motivation, interest, and do not under-stand the ideas of what they read.

The difficulties above may be caused by many factors, such as teachers, materials, teaching techniques, facilities, etc. Many kinds of experiences bring teachers to a perfect teaching. How teachers treat students as a group or as an individual in managing classroom situation is extremely important and affects the students' achievement in learning.

The material used should be well considered. It is supported by Eskey in Simajuntak (1988: 12) who declares that once reading material appropriate to the level and interests of particular students has been identified, the more of material that the students read, the better and the more quickly his reading will develop. Therefore, teachers should choose the materials which are relevant to the learners' need and interest. In other words, they should be appropriate for the learners.

Teaching techniques are usually implementational, and they take place in a classroom. It can be said that techniques depend on the teacher, his individual artistry, and on the composition of the class. Particular problems can be tackled equally successfully by the use of different techniques. Actually, there are many kinds of techniques in teaching reading, such as teaching reading through Pictures, SQ3R, SQ4R, CALLA, Cloze Procedure, and other techniques in teaching reading.

From the points discussed above, Cloze Procedure can be chosen as one of 
many possible techniques in teaching reading. In using the cloze procedure technique, one will not think that reading is a passive activity, but it is an active one, in which s/he has to make a number of predictions or ask specific questions of each deletion. Every time s/he answers these questions correctly, the process of successful comprehension is taking place. In addition, in using this technique, a teacher may train students to guess. They are encouraged to take risks and to take a chance. It means that, sometimes, the guesses can be wrong.

\section{DISCUSSION}

\section{The Concept of Reading}

According to Nunan (1999), reading is a process of decoding written symbols, working from smaller units (individual letter) to large ones (words, clauses, and sentences). It means that one needs to use strategies to decode written forms in order to arrive at meaning. To make sense of a text, beginners must depend more extensively than fluent readers do on the visual information provided by the print. When they become familiar with both language and conventions of the printed pages and the subjects they have chosen to read about, they put that knowledge to use in reconstructing the meaning of those texts. Thus the reading that the proficient reader does is a very different thing from the reading that s/he once did as a beginner. In the process of acquiring reading skills, the EFL reading teacher must develop sensitivity to what her/his students know and what her/his students he is trying to help.

While, Grellet (1981:3) states that reading is a process of understanding a written text means the required information from it as efficiently as possible. It means that a competent reader will quickly reject the irrelevant information and find what $\mathrm{s} / \mathrm{he}$ is looking for. It is not enough to understand the ghost of the text; more detail comprehension is necessary. Therefore, according to him, a reader needs to consider about what does s/he reads (novel, letters, textbook, etc), why s/he reads (reading for pleasure information or reading for finding out something and /or to do something with the information we get), how s/he reads (skimming, scanning, extensive reading, or intensive reading), and so on. Clearly, in real life a reader's reading purpose can strongly vary and therefore, when devising exercises, s/he should vary the questions and the activities according to the type of the text studied and the purpose in reading. He also states that reading involves a variety of skills. They are:

1) Recognizing the script of language

2) Deducting the meaning and the use of unfamiliar lexical items

3) Understanding explicitly stated information

4) Understanding information when not explicitly stated

5) Understanding conceptual meaning

6) Understanding the communication value (function) of sentences and utterance

7) Understanding relation within the sentence

8) Understanding relation between the parts of a text through lexical cohesion devices

9) Understanding cohesion between parts of a text through grammatical cohesion devices

10) Interpreting text by going out side

11) Recognizing indicator in discourse

12)Identifying the main point or important information in a piece of discourse

13)Distinguishing the main idea from supporting details

14)Extracting salient points to summarize ( the text, an idea, etc) 
15)Selective extraction of relevant points from a text

16)Basic inference skill

17)Skimming

18)Scanning to locate specifically requireed information

19) Transcoding information to diagrammatic display. (Grellet, 1981:139)

In order to develop these skills, several types of exercises can be used. These question-types can have two different functions. They are: 1) To clarify the organization of a passage; the question can be about: the function of the passage, the general organization, such as an argumentative, the rhetorical organization, such as contrast and comparison, and the cohesive devices, such as link-world, the intra-sentential relations such as derivation, morphology, hyponymy, etc. 2) To clarify the content of a passage; the question can be about: plain fact such as direct reference, deduced meaning such as supposition, implied fact such as inference, and evaluation.

Then, Mei Yun (2010: 12) states that reading is an interactive process of communication. It means that through text the writer can encode a message, and through it the reader also gets the meaning of a message by decoding it. Furthermore, Sheng (2000:12-13) states that reading involves the recognition of letters, a simpler process than comprehension. It is not only important for the reading teachers to form a concept of a reading process, but also they distinguish between reading process and reading instruction externally (Miller: 1984). It is clear that reading is process of communication from the writer to the reader.

In addition, Ur (1991: 148) declares that there are 8 characteristics of efficient reading. They are as follows:
1) The language of the text is comprehensible to the learners (Language).

2) The content of the text is accessible to the learners; they know enough about it to be able to apply their own background knowledge (Content).

3) The reading progress fairly fast: mainly because the reader has 'authomatized' recognition of comm.on combination, and does not waste time working out each word or group of words a new (Speed).

4) The reader concentrates on the significant bits and skims the rest; may ever skip parts he or she knows to be insignificant (Attention).

5) The reader takes incomprehensible vocabulary in his or her stride: guesses its meaning from the surrounding text, or ignores it and manages without; uses a dictionary only when these strategies are insufficient (Incomprehensible).

6) The reader thinks ahead, hypothesizes, and predicts (Prediction).

7) The reader has and uses background information to understand the text (Background information).

8) The reader is motivated to read: by interesting content or a challenging task (Motivation).

9) The reader is aware of a clear purpose in reading: for example, to fain out something, and/or to get pleasure (Purpose).

10) The reader uses different strategies for different kinds of reading (Strategy).

\section{The Concept of Reading Compre- hension}

According to Devine (1986:67), reading comprehension is process of using syntactic and semantic information found in printer text to reconstruct in the reader's mind. The opinion is supported by Nuttal (1982: 18) who states that reading comprehension is the transfer of 
a message from a writer to readers, the transfers of meaning mind to mind. She also defines reading comprehension as the meaningful interpretation of printed of written verbal symbols. It means that reading is a result of the interaction between the perception of graphic symbols that represent language, and the reader's language skills, and the knowledge of the world. In this process, a reader has to create the meaning intended by the writer. It should be noted that the writer, the reader and the text have a unique contribution to make communication is to take place.

Besides, Sheng (2000:13) states that reading comprehension is a process of negotiating understanding between the reader and the writer. In this case, there are some factors involved, such as cognitive and emotional factors and linguistic factors (phonology, morphology, syntax, semantic, and pragmatic element). Clearly, reading needs the ability to comprehend the meaning what is read.

Furthermore, Mohammad (2003) states that there are actually three main levels or strands of comprehension. They are literal, interpretive, and critical comprehension. Literal comprehension is the most obvious. It only involves surface meanings. For example, a teacher can ask his students to find information and ideas that are explicitly stated in a text. In interpretive or referential comprehension level, the students go beyond what is said and read for deeper meanings. Here, they should be able to read critically what they have read. They also need to know how to find the related ideas and implied meaning of a text. So, this level includes thinking process such as drawing conclusions, making generalizations, and predicting outcomes. Then, the third level is critical reading. In this level ideas and information are evaluated. Critical evaluation occurs only after the students understood about the ideas and information that the authors want to express to the readers.

Then, Gusmawati in Nadrah (2004:12) states that there are at least three levels of comprehension: literal, interpretative, and applied levels. In literal level, the readers deal with decoding the symbols use in the text only, but in interpretative and applied levels, the readers have to grasp the ideas to interpret and apply what they read.

Based on the explanation above, it can be conclude that reading comprehendsion is a mental process by which the reader takes the meaning or the content of the text that is expressed by the author and use them to construct an interpretation of what $\mathrm{s} / \mathrm{he}$ thinks the author intended to convey. In reading comprehension, the reader should know how to understand a text, how to understand a paragraph, and how to make conclusion when s/he get unstated ideas from the text that $\mathrm{s} / \mathrm{he}$ is reading.

\section{The Cloze Procedure Technique}

The cloze procedure as a teaching technique has been used since about 1970, and since then many studies have demonstrated its effectiveness. Richardson in Trimble (1989:21) states that the cloze procedure provides both teacher and the students with a new and stimulating way to acquire and apply skills. The myriad uses of the cloze procedure coupled with the simplicity of construction make it a very useful tool for each classroom.

According to Honeyfield in Jacobsen (1981:25), the main goal of language teaching may be to enable learners to perform the four language skills namely: listening, speaking, reading and writing. The central tasks of language teachers are to implement and to evaluate the instruction. It is necessary to have the intended outcomes of purposes clearly in mind. The process 
that the teacher uses to define the desire learning outcomes can significantly affect the results off the instruction.

Teaching may be defined as the process of supplying condition favorable to learning. The teaching of reading is no exception. A teacher should create active learning condition and develop their technique to help learners communicate more effectively by considering suitable activities for each group of learners.

One of the teaching techniques to improve reading comprehension is cloze procedure. According to Taylor in Trimble (1989:20), cloze procedure is a process of systematically deleting words from a passage and replacing them with blanks to be filled by the students. Cloze is a term 'gestalt- psychology' applies to the human tendency to complete a familiar but not quite finished pattern to see a broken circle has a whole one.

\section{The Advantages of Cloze Procedure Technique}

The cloze procedure has been used as:

a. To diagnose the students' level

To know whether the material is at the appropriate level of difficulty, a teacher can give the diagnostic test. One way to diagnose students' present level of comprehension is to have them answer comprehension questions about passage, at different level of difficulty. Another way to diagnose is by using a cloze procedure. Bormuth in Trimble (1989:25) claims that the cloze procedure is a useful tool for checking the readability of printed materials for individual. Every fourth or fifth word beginning with the third line is taken out of the text. The students study the passage and fill the blanks with an appropriate word. In order to do this, the students have to understand the vocabulary and syntactic surrounding the blanks.

b. To develop letter, word, and meaning identification

Bastidas (1984:21) declares that the cloze procedure can be used effectively to develop letter identification, word identification and meaning identification. It is clear that since the purpose here is to demonstrate its use in developing reading comprehension, we will emphasize meaning identification. When working with the cloze passage containing systematic deletions occurring every fifth, sixth, seventh or tenth word, the students are being trained to predict the meaning of a phrase in order to identify the missing words. The meaning identification is immediate in the sense that it does not require individual word and letter identification. The student is working with the contextual clues.

c. To improve reading comprehension Cloze procedure has been used as a testing technique since its inception. It's has been most effectively used in teaching reading comprehension. In using the cloze procedure technique as a teaching technique, someone is training his/her students to guess. They are encouraged to take risks and to take a chance. It means that sometimes the guesses will be wrong. Smith in Mikulecky (2004:12) states that reading can be a risky business, but one gets useful information when errors appear, they may provide a good opportunity to learn.

At last, Smith in Mikulecky (2004: 32) also states that there are several advantages of using cloze procedure as a teaching technique. Those advantages are 1) in using the cloze procedure, one can see that reading is not a passive activity, but a very active one, in which the student must make a number of 
predictions or ask specific questions for each deletion. Every time s/he answers these questions correctly, the process of successful comprehension is taking place, and 2) the cloze procedure is congruent with many important principles of the psycho-linguistic approach to reading, which gives it a prominent place among techniques used to increase reading comprehension.

\section{Selecting Material for Cloze Procedure Class}

The cloze procedure can be taken from a variety of source. The selection depends on how and what the objectives we have stated. In this case, Richardson in Kustaryo (1988:19) suggests the following ways:

a. Choosing the passages that have high interest level and at the reading level of our students.

b. Preparing our own material with special purposes.

c. Selecting a short story.

d. Selecting passages with pictures to help the students understand the passage.

e. Preparing word cards to complete the meaning of sentences.

The cloze procedure, however, must be viewed as a supplement to other techniques for improving reading comprehension, and it must not be averused, since this will lead to frustration and boredom on part of the students.

\section{How to Construct and Present Cloze Procedure in Classroom (As Model)}

When a teacher constructs his/her materials, s/he should adapt them to his/her specific students, purposes, content areas, concepts and carefully sequence them according to length and difficulty. Richardson in Kustaryo
(1988:20) suggests us the following procedure:

a. Deleting systematically every fifth or seventh word but leaving either consonant, vowel or final letter.

b. Using the long passage and keeping the context of semantic and syntax in mind.

c. Precede the passage with brief and clear direction.

\section{A Sample of the Application of the Cloze Procedure Technique in Classroom}

A. Direction: Fill in the blanks with an appropriate word, the dashes will indicate the number of letters you fill in!

The population of the world is growing quickly. The growth is very __ _ in some countries which

do not have enough $\ldots \ldots$ for their people. The _-_- $----{ }_{-}$of many of these $\ldots \ldots \ldots \ldots \ldots \ldots$ are trying to limit _ _ number of babies being _. They say "stop after _ _ _ children, small is beautiful!" _ _ _ children is a good _ _ _ for your family. These

_ $\ldots \ldots \ldots \ldots$. $\ldots$ have programs which show _ _ _ people modern methods of control. But not everyone

- - with these programs. The

who are against

programs say thing like programs say thing like " -----_ _ cannot control the lives _ _ people. They cannot decide _ _ _ size of families. There _ _ enough food in the _ _ _ - for everyone." Clearly, not _ _ $\ldots \ldots \ldots$ accepts birth control _ _ a solution to the _ _ _ _ _ population, and many $\ldots+-{ }_{-}$control programs are failure.

B. Answer the questions below!

1. How is the population growing in the world? 
2. What do the governments do to limit the growth of the population?

3. What do the people think about this program, do they agree or not?

4. According to the text, what are the government problems in the world?

5. What are the government suggestions in this program?

The teaching procedure in applying the Cloze Procedure Technique in classroom is as follows:

1. A teacher begins the class by stating the purpose of the activity and announces the title of the passage.

2. If the students are not familiar with the cloze procedure, the teacher should devote some time to explain its purpose and how to guess the missing words with the helps of context.

3. The teacher hands out the cloze procedure passage and asks the students to read silently.

4. The teacher reads the passage loudly, trying to maintain a correct intonation and making the necessary pauses.

5. The teacher asks the students to read the first paragraph silently, afterward the teacher directs discussion with the whole group participating.

6. The teacher gives some clues to help student to find the correct or acceptable words.

7. After the first paragraph has finished, the teacher asks the student to read it aloud to see whether it makes sense.

8. The teacher shows the original paragraph, and asks the student to compare it with the one they have just completed.
9. In order to provide variety, the teacher divides the class into groups and asks them to read the text paragraph.

10. While the student are working in groups, the teacher should interact witch each group and works as a facilitator.

11. The teacher asks the students to report their findings.

12. Finally, the teacher shows again the original paragraph and compares it with the student's answers. (Richardson in Kustaryo, 1988:20)

The answer key of the material:

$\begin{array}{ll}\text { A. 1. fast } & \text { 14. agrees } \\ \text { 2. already } & \text { 15. people } \\ \text { 3. food } & \text { 16.government } \\ \text { 4. governments } & \text { 17.government } \\ \text { 5. countries } & \text { 18.of } \\ \text { 6. the } & \text { 19.the } \\ \text { 7. born } & \text { 20.is } \\ \text { 8. two } & \text { 21.world } \\ \text { 9. two } & \text { 22.everyone } \\ \text { 10. size } & \text { 23.as } \\ \text { 11. governments } & \text { 24.problem } \\ \text { 11. poor } & \text { 25.birth } \\ \text { 13. birth } & \end{array}$

B. 1. The growth of the population in the world is fast.

2. The governments are trying to limit the number of the babies being born.

3. Not everyone agrees with this program, and not everyone accepts birth control as a solution to the problems of population.

4. According to the text, the government's problems are the growth of the population which is very fast and the people who are against the government's program.

5. The government's suggestions are "stop after two children, small is beautiful. Two children is a good size for your family. 


\section{CONCLUSIONS AND SUGGES- TIONS}

\section{Conclusions}

Based on the discussion above, the cloze procedure can increase the students' reading ability. It may provide a student with a challenge experience in reading activity. S/he can evaluate his/her knowledge of reading through guessing missing words. Through this method, the students automatically ought to increase their speed and fluency in reading. In addition, it also gives the students a good chance to increase their English vocabularies.

\section{BIBLIOGRAPHY}

Bastidas, A Jesus. The Cloze Procedure Technique as a Teaching Technique to Improve Reading Comprehension. English Teaching Forum. Vol.XXII No. 2 April. 1984.

Devine, Thomas G. Teaching Reading Comprehension from Theory to Practice. Boston: Allyn and Bacon. 1986.

Grellet, Francoise. Developing Reading Skills: A Practical Guide to Reading Comprehension Exercises. Cambridge: Cambridge University Press. 1981.

Jacobsen, D. Dulaney and Eggen. Methods for Teaching. Toronto: Charles E Merill Publishing Company. 1981.

Kustaryo, Sukirah. Reading Technique for College Students. Jakarta: Depertemen Pendidikan dan Kebudayaan 1988.

\section{Suggestions}

Since the goal of reading comprehension class is to help the students gain the information from printed materials, the cloze procedure materials may be helpful. So, it may be advisable for the English teachers to use cloze procedure in teaching reading in English classroom.

It is also suggested to English Department students to increase their reading skill by applying this technique under the teacher's instruction in reading activity. And, by involving their experience as well as possible they can build their knowledge of English through this technique.

Mei Yun, Y. Cohesion and the Teaching of EFL Reading. English Teaching Forum. Vol. 31 No.2, P.12, 2010.

Mikulecky, S Beatrice. Basic Reading Power: Reading for Pleasure, Comprehension Skills, Thinking Skills, Reading Faster. New York: Long Man Inc. 2004.

Miller, Wilman H. Teaching Reading in Today's Elementary Schools. Boston: Houchton Mifflin Company. 1984.

Mohammad, Akmar. "What do We Test When We Test Reading Comprehension.

http://www.aitech.ac.Tp/ iteslj. 2003.

Nadrah. The Contribution of Reading Strategies and Vocabularies Mastery to Reading Comprehension of the Third Year High School Students in Padang. Unpublished Thesis. Padang: Program Pasca- 
sarjana Universitas Negeri Padang. 2004.

Nunan, David. Language Teaching Methodology. London: Pearson Education, Ltd. Third Edition. 1999.

Nuttal, Christine. Teaching Reading Skills in a Foreign Language. London: Merill Publishing Company. 1982.

Sheng, He Ji. A Cognitive Model for Teaching Reading Comprehension. English Teaching Forum. December, 38 (4):12-13. 2000.

Daftar Indeks

procedure, $37,38,40,41,42,43,44$
Simajuntak, Edithia Gloria. Developing Reading Skills for EFL Students. Jakarta: Depertemen Pendidikan dan Kebudayaan. 1988.

Trimbel, Louis. A Rhetorical Approach to Reading Scientific and Technical English. English Teaching Forum. 1989.

Ur, Penny. A Course in Language Teaching: Practice and Theory. Cambridge: Cambridge University Press.

1991.

reading, $37,38,39,40,41,42,44$ 